\title{
Comparative Advantage of Turkish Olive Oil in Global Markets: An Empirical Analysis
}

\author{
Abdulmusa Sönmüş̧, ${ }^{1, a, *}$, Mehmet Hanifi Aslan ${ }^{2, b}$ \\ ${ }^{1}$ Unal Tourism, Turkey \\ ${ }^{2}$ Faculty of Economics, Administrative and Social Science, Hasan Kalyoncu University, 27410 Gaziantep, Turkey
}

*Corresponding author

A R T I C LE IN F O A B S T R A C T

\section{Research Article}

Received : 13/04/2021

Accepted : 18/05/2021

Keywords:

Revealed Comparative Advantage

RCA Index

Comparative Advantage

Competitiveness

Export Performance

Purpose: This study aims to reveal the comparative advantage of the selected countries in olive oil industry. These selected countries are the main olive oil producers and mainly located in Mediterranean Seacoast. Spain, Italy, Greece and Turkey will be the subject countries in this analysis and compared with each other in terms of their export performance and comparative advantage in olive oil industry globally. Olive oil industry has a volume of around 20 billion Euros every year. Design/methodology/approach: The data for the research was collected from mainly World Bank and trade ministries of subject countries. Revealed Comparative advantage Index (RCA) is used to compare the advantage of these countries in olive oil industry. These indexes found in this analysis will be added to the olive oil RCA indexes of these countries that are found in the previous researches. The obtained data were analyzed through RCA Index formula modeling. Findings:Consuming olive oil is increasing day by day over the world. The research results show that Turkey has comparative advantage in olive industry over Greece. Last few years, Turkey has improved its comparative advantage over Italy. Spain and Italy are the leading countries in olive oil industry in terms of comparative advantage. It has also been found that Turkey has consistently increase its advantage over the last decade. Practical implications: After the comparison of RCA indexes of Spain, Greece, Italy and Turkey, it is found that higher amount of production of olive oil is not enough itself to improve the competitiveness of a country in olive oil market. Branding, packaging and marketing activities that are supported by research and development expenditures are highly important factors for a consistent competitive advantage in olive oil industry. Olive oil consumers are highly motivated on the packaging and label of a product when it comes to olive oil. They usually trust Mediterranean brands comparing to others. Originality/value: The study answers the advantages of selected countries in terms of olive oil performance in global markets. Export performance of olive oil is much likely to improve the competitiveness of a country rather than a country that produces high volume of olive oil. Production itself is not enough to increase competitiveness of a country in olive oil market.

\section{Introduction}

Mediterranean countries are not only mainly olive oil producers in the world, but also the mainly consumers of olive oil in the world. Turkey is also an important olive oil produces in the region, which is ranked as third country after Spain and Italy, and it has a great potential to increase its competitiveness in olive oil sector (Mylonas, 2015). In terms of comparative advantage in olive oil industry between Spain, Italy, Greece and Turkey, it is analysed that Turkey is in the third place in the world. However, when it comes to Global Competitiveness Index (GCI) report in 2019, Turkey was ranked on $61^{\text {st }}$ place in terms of general competitiveness criteria. Therefore, being on third place in olive oil industry for Turkey creates a potential advantage and adaption to the sector when comparing the GCI report. GCI index is found by considering countries' general and structural factors. Such as, financial development, Income level, and structural factors. In this research, Revealed Comparative Advantage Index, which is sector-based competitiveness analysis, will be used to compare the advantages of olive oil industry for selected countries of Spain, Italy, Greece and Turkey. Tukey must improve the agricultural and trade policies, cooperation between the producers of olive oil and support the marketing activities to increase its competitiveness in global markets (Gürkan, 
2015, p. 61). According to International Olive Oil Council (IOC) report in 2018, around 2,9 million tons of olive oil was produced in the world. Almost 1,8 million tons of this total amount of olive oil was produced by member countries of European Union. Spain and Italy are the important olive oil producers in the Euro zone. Turkey is the third country as olive oil producer after Spain and Italy with 177,000 tons of olive oil production in 2018. Meanwhile, Italy has the highest income from global olive oil industry by having professional branding and marketing activities and support of its government's agricultural policies (Turkekul, 2010, p. 8). In addition to Italian government's support for production of olive oil, trade policy of zero taxes on import of olive oil that will be exported to third countries is also empowers Italian competitiveness in the industry.

\section{Literature Review}

Researches on olive oil industry are mainly made by agricultural and trade ministries of countries, universities and research institutions. International Olive Oil Council (IOC), which is originally located in Spain, is the highest institute on olive oil sector' statistics and data collection. IOC also imposes rules and regulations to keep the quality of olive oil that is internationally moved to final consumers. At it is discussed before, new world actor countries, which are United States of America, Argentine and Australia, produce nearly $10 \%$ of their olive oil consumption and import the rest of the amount from mainly Italy and Spain (William, 2013, 8). Nowadays, new world actor countries are making great number of researches in order to increase and make extra profit out of olive oil industry.

Literally, there are few researches on competitiveness of Turkish olive oil and the ones who has chosen this topic also used RCA Index modelling to make comparison of Turkish activity in olive oil market globally (Lynch, 2013, p. 2)
Between 1995 and 2004, Spain had the highest olive oil comparative export performance (CEP) index over Italy, Greece and Turkey. Second highest CEP index was calculated for Greece, third Italy and Turkey had the fourth place in the analysis. Same years, Italy had the highest olive oil RCA index over these countries. Spain was ranked as second and Greece and Turkey were $3^{\text {rd }}$ and $4^{\text {th }}$ in order (Serin, 2008, p. 7).

\section{Global Olive Oil Market}

Countries that are located in Mediterranean seacoast are producing almost \%97 of total world olive oil production. Out of total world olive oil production, $\% 45$ is produced by Spain, \%16 by Italy, and \%10 is by Greece. The rest of $25 \%$ of olive oil is produced by other countries including Turkey. Same countries that are located in Mediterranean also consumes the $\% 80$ of total world olive oil production. $23 \%$ is consumed by Italy, $\% 19$ by Spain and $\% 17$ is consumed by Turkey. Even though USA produces $\% 1$ of total world olive oil production, it consumes almost $9 \%$ of total amount. In Table 1, mainly olive oil producers and their ratios to total production is shown (Production, IOC, 2019).

As it is seen in Table 1, highest amount of olive oil production is made by member countries of European Union throughout 2012 and 2018. Tunisia, Turkey and Syria are the highest olive oil producing countries after the EU. As olive oil production increases over time, olive oil consumption is also increased. In Table 2, olive oil consumption amounts and changing ratio of consumption from 1991 to 2017 is shown (Soyyigit, 2018, p. 3). Olive oil consumption has increased in Japan over 12 times in 2017 comparing to the consumption level in 1991. United Kingdom has also increased the consumption level of olive oil over 7 times through the same timeline. Except Italy and Greece, most of the countries have increased the consumption of olive oil as time goes.

Table 1. 2012 - 2018 Olive Oil Production / 1000 tons

\begin{tabular}{l|ccccccc}
\multicolumn{1}{c}{ Country } & 2012 & 2013 & 2014 & 2015 & 2016 & 2017 & 2018 \\
\hline Argentina & 39,5 & 66 & 44 & 69,5 & 82 & 63 & 80 \\
European Union & 2,395 & $1,461.5$ & $2,482.50$ & $1,434.5$ & 2,324 & $1,747.5$ & 1,805 \\
Algeria & 39,5 & 66 & 44 & 69,5 & 82 & 63 & 80 \\
Syria & 198 & 175 & 180 & 105 & 110 & 110 & 100 \\
Morocco & 120 & 100 & 130 & 120 & 130 & 110 & 140 \\
Turkey & 191 & 195 & 135 & 160 & 150 & 177 & 287 \\
Tunisia & 182 & 220 & 70 & 340 & 140 & 100 & 220 \\
\hline
\end{tabular}

Table 2. 1991 and 2017 Olive Oil Consumptions / tons

\begin{tabular}{l|ccc}
\hline \multicolumn{1}{c|}{ Country } & 1991 & 2017 & Change in Consumption \\
\hline Japan & 4,000 & 55,000 & $1275.00 \%$ \\
United Kingdom & 6,800 & 58,400 & $758.82 \%$ \\
Germany & 10,300 & 61,600 & $498.06 \%$ \\
Brasilia & 13,500 & 59,500 & $340.74 \%$ \\
Russia & 5,000 & 19,500 & $290.00 \%$ \\
France & 28,000 & 94,000 & $235.71 \%$ \\
USA & 88,000 & 315,000 & $257.95 \%$ \\
Portugal & 27,000 & 70,000 & $159.26 \%$ \\
Turkey & 55,000 & 155,000 & $181.82 \%$ \\
Spain & 394,000 & 457,200 & $16.04 \%$ \\
Italy & 540,000 & 514,000 & $-4.81 \%$ \\
Greece & 204,000 & 105,000 & $-48.53 \%$ \\
\hline
\end{tabular}


Olive Oil Market Structures in Spain, Greece, Italy and Turkey

Italy consumes nearly all amount of olive oil that is produced in the country. If there is surplus of olive oil in the market, the amount of surplus is sold directly to wholesalers. Wholesalers are playing an important role in Italian olive oil market. These wholesalers make profit both in local market and international markets. Italy is known as professional olive oil packaging, branding and marketing country that is now known worldwide by customers. Italy imports olive oil as bulk and markets the product under Italian brands (European, 20012, p. 8). In Italy, olive oil sector is pumped by two factors. First, olive producers transfer the olives to local mills. Second is that the amount of olive oil directly imported from other countries. Both of the amounts of olive oil go into the packaging facilities. Then the final product is ready for local retailers and wholesalers. Sometimes Italian olive oil producers may also directly export their product since Italian brand is known worldwide nowadays (Bakircioglu, 2006, p. 109).

Spain has an agricultural policy that supports producing high volume of olive oil in the country. This program has been working well and allowing Spain to act efficiently in global olive oil market. Comparing to Italian olive oil market structure in Italy, the amount of olive oil that is produced in Spain is usually bought by the local mills and national olive oil cooperatives. These cooperatives highly efficient in Spain and controlling the olive oil market in the country. After packaging olive oil by mills or cooperatives, final product is ready for local consumption and exportation. Cooperatives do not make export process through the wholesalers, they usually contact the buyers directly, which is unsimilar to the market structure in Italy. Olive Oil market structure is much more similar to the structure in Spain rather than Italy. Again, produced olive oil in Greece bought by private mills and cooperatives. However, mills sell the olive oil to the wholesalers, then product goes to local market or mills directly can export the final product. Cooperatives transfer the olive oil to the packaging associations that is connected to European Union subventions program. These associations then make final product ready for local and international consumption (Bakirlioglu, 2006, p. 130). In Turkey, olive oil market is most likely small family business that is not well organized from production to the final consumers. 8 million of total population make income out of Turkish olive oil market. Comparing to Spain, Greece and Italy, cooperation is not well organized in Turkey and has lower role in the industry. Government in Turkey is not acting efficiently in olive oil industry (Aydin, 2018, p. 747).

Turkish producers sell the olive oil to local brokers and wholesalers after they stock the amount of their own consumption. 47 percent of producers sell the olive oil to the brokers and 24 percent sell it to the local mills. Brokers are also selling olive oil to the mills. The amount of olive oil that is stocked in mills is bought by wholesalers, local retailers or directly exported (Seçer, 2018, p. 50).

\section{Methodology}

Researches that are motivated on international trade are started using Revealed Comparative Advantage Index (RCA) to analyze the sector-based advantages of countries after 2000. The formula of RCA index is shown below (Bennedicts, 2001, p. 35).

$$
\operatorname{RCA}_{\mathrm{ij}}=\left(\mathrm{X}_{\mathrm{ij}} / \mathrm{X}_{\mathrm{i}}\right) /\left(\mathrm{X}_{\mathrm{aj}} / \mathrm{X}_{\mathrm{a}}\right)
$$

The letter i represents a country, j represents an industry and a represents the world. In this research, $i$ will be used for Spain, Italy, Greece and Turkey in a rotation in terms of the export amount of olive oil. The letter $j$ will represent the amount of total olive oil that is exported in the industry. Finally, letter a will represent the total amount of olive oil that is exported in the industry in the world. All numbers will be from the same timeline in this analysis. Previous researches have calculated RCA indexes in olive oil industry for the selected countries in this analysis (Turkekul, 2010) and shown on Table 3. As RCA index of a country increases, country's competitiveness in the industry will also increase. In 1996, in olive oil sector, Italy had comparative advantage over Spain, Spain had comparative advantage over Greece and Greece had comparative advantage over Turkey. However, these advantages seem to change as it is shown on Table 3; in 2006, Spain has comparative advantage over Italy, Italy has comparative advantage over Turkey and Turkey is now on $3^{\text {rd }}$ place and has comparative advantage over Greece in olive oil industry.

Greece seems to lose its comparative advantage on olive oil industry throughout time. Thus, when RCA index is lower than 1, it can be said that country does not have any comparative advantage in this industry. Table 4 shows the criteria of RCA indexes and what the indexes mean for a country's level of competitiveness in the industry (Topçu, 20, p. 335)

Table 3. 1996 - 2006 Olive Oil RCA Indexes of Greece, Italy, Spain and Turkey

\begin{tabular}{l|cccc}
\hline Date & Greece & Italy & Spain & Turkey \\
\hline 1996 & 2.65 & 8.05 & 1.08 & 2.50 \\
1997 & 1.85 & 7.47 & 1.26 & 2.81 \\
1998 & 1.85 & 7.41 & 1.22 & 3.14 \\
1999 & 2.63 & 7.54 & 7.66 & 6.84 \\
2000 & 1.42 & 9.94 & 1.07 & 1.51 \\
2001 & 1.73 & 8.41 & 1.11 & 6.53 \\
2002 & 1.33 & 8.52 & 1.32 & 2.37 \\
2003 & 1.60 & 7.76 & 1.09 & 5.79 \\
2004 & 1.60 & 10.35 & 1.14 & 3.42 \\
2005 & 1.22 & 8.15 & 8.09 & 4.28 \\
2006 & 1.33 & 8.31 & 9.20 & 4.05 \\
\hline
\end{tabular}


Table 4. RCA Index Criteria for Competitiveness Level

\begin{tabular}{l|cc}
\hline \multicolumn{1}{c|}{ Class } & RCA Value & Competitiveness \\
\hline A Class & $0<$ RCA $<1$ & Disadvantage \\
B Class & $1<$ RCA $<2$ & Low Advantage \\
C Class & $2<$ RCA $<4$ & Medium Advantage \\
D Class & $4<$ RCA & High Advantage \\
\hline
\end{tabular}

Table 5. 2009 - 2018 Olive Oil RCA Indexes of Spain, Italy, Turkey and Greece

\begin{tabular}{l|cccc}
\hline \multirow{2}{*}{ Date } & Spain & Italy & Turkey & Greece \\
\hline 2009 & 9.24 & 7.44 & 4.40 & 3.62 \\
2010 & 12.49 & 8.54 & 4.38 & 4.25 \\
2011 & 9.29 & 7.51 & 1.34 & 3.66 \\
2012 & 13.64 & 9.02 & 2.22 & 5.04 \\
2013 & 9.95 & 7.98 & 9.77 & 5.56 \\
2014 & 15.26 & 8.36 & 3.81 & 4.94 \\
2015 & 12.03 & 8.73 & 3.05 & 5.29 \\
2016 & 14.94 & 7.85 & 1.66 & 6.89 \\
2017 & 12.74 & 7.33 & 4.39 & 2.15 \\
2018 & 9.33 & 6.13 & 7.21 & 2.27 \\
\hline
\end{tabular}

To have a substantial comparative advantage on an industry, RCA index must be higher than 4 for a country. In this research, RCA indexes of these selected countries are calculated by using the same source of data and modelling. Table 5 shows the RCA indexes of Spain, Italy, Greece and Turkey between 2009 and 2018. Turkey seems to have kept its comparative advantage over Greece in olive oil sector since 1996. In addition, Turkey has comparative advantage over Italy in 2018.

RCA indexes of Spain are consistently higher than RCA indexes of Italy, Greece and Turkey as seen in Table 5. Spain has comparative advantage in olive oil industry over all selected countries of Greece, Turkey and Italy. Italy is the second country that has a comparative advantage over Turkey and Greece. In 2013 and 2018, Turkey had comparative advantage over Italy. It is seen that Turkey and Italy has similar RCA indexes which may be a potential for Turkey to be in the second place in the future in terms of competitiveness of Turkish olive oil in global market.

\section{Result and Discussion}

In this research, competitiveness of Turkish olive oil in global market is analysed and compared to main actor countries in this market of Spain, Italy and Greece. RCA indexes are calculated for each country and used to make comparisons of these selected countries' olive oil export activities and comparative advantages over each other. Overall, it is concluded that Turkey is the $3^{\text {rd }}$ country that has a comparative advantage on olive oil industry after Spain and Italy. As it is said above, Turkey had comparative advantage over Italy for a couple of years and Turkey has a potential to increase its advantage in olive oil industry. Findings in this research has similarities with Abay's research in 2006 and named as "Competitive Analysis of Olive Oil in Globe". In his research, Abay stated that Italy has comparative advantage over Turkey and Greece in olive oil market by using Constant Market Share analysis model. Another research that has similar results in this research was made by Anania in 2008 and named as "The Global Market for Olive Oil". Anania found that Spain is the leading country in olive oil industry; and, Turkey, Italy and Greece are the following leader countries. Anania use OLS regression analysis to compare these countries olive oil industries. In addition to these analyses, in order to improve competitive advantage of a country in olive oil sector, a panel data analysis will show the factors effecting RCA index, which is made in this research. RCA index is chosen as dependent variable and countries' foundational factors are chosen as independent variables. Table 6 shows the Fully Modified Ordinary Linear Square (FMOLS) analysis results.

Using the RCA indexes that are calculated in this research as a dependent variable in Panel data will show the impact of the independent variables on competitive advantage of these countries in olive oil Industry. As seen in Table 6, the effect of cost of producing olive oil (LnP) on RCA index has unsignificant since it has a p-value of 0.5126 , which is greater than 0.10. In other words, according to the panel data results, lower producing ccc coo olive oil had no impact on comparative advantage of countries between 2009 and 2018. The effect of income level ( $\mathrm{LnI}$ ) on RCA is also unsignificant since its p-value is also greater than 0.10 . Income level of a country did not have any impact on olive oil RCA index. As shown in Table 6, the impact of financial development of a country on RCA index is significant with a p-value of 0.0166 . This variable's coefficient is one of the highest in the panel data. In other words, countries with higher financial development have an advantage on global olive oil industry. The impact of Reel Effective Exchange Rate (RE) also is significant with a p-value of 0.0503 . When exchange rate increases, comparative advantage of a country also increases. The impact of Agricultural Total Factor Productivity (ATFP) on RCA is significant with a p-value of 0.0841 . In this panel data analysis, the coefficient of ATFP is the highest; therefore, increasing the total factor efficiency in olive oil production will enhance the comparative advantage of these selected countries. Impact of research and development expenditure (RD) on RCA index is significant with a p-value of 0.0215 . 
Increasing RD expenditures on olive oil industry will have positive impact on RCA and will enhance the comparative advantage. Agricultural Subvention's impact on RCA is significant with a negative effect. This means that farmers or producers of olive oil might not use the funds efficiently in olive oil sector. Market Power's (MP) impact on RCA is significant with a positive effect. This may support the marketing success of Italian brands' well-being in global olive oil industry.

Table 6. Panel Data Analysis of 2009 - 2018 RCA Indexes of Spain, Greece, Turkey and Italy

\begin{tabular}{|c|c|c|c|c|}
\hline R-Square & 0.858317 & Standard Error & t-stat & P-value \\
\hline Adjusted R-Square & 0.793378 & & & \\
\hline Standard Error & 1.725 .173 & & & \\
\hline $\mathrm{n}$ & 36 & & & \\
\hline Dependent Variable & RCA & & & \\
\hline Panel Metod & Grouped & & & \\
\hline Independent Variable & Coefficient & & & \\
\hline $\mathrm{LnP}$ & -1.135031 & 1.707721 & -0.664647 & 0.5126 \\
\hline LnI & -2.481361 & 3.393139 & -0.731288 & 0.4717 \\
\hline FD & 6.720005 & 2.640005 & 2.543809 & 0.0166 \\
\hline $\mathrm{RE}$ & 0.148180 & 0.071913 & 2.060544 & 0.0503 \\
\hline ATFP & 9.963923 & 5.529465 & 1.801969 & 0.0841 \\
\hline $\mathrm{RD}$ & 7.401886 & 3.045758 & 2.430228 & 0.0215 \\
\hline LnAS & -7.034214 & 2.180170 & -3.226451 & 0.0036 \\
\hline MP & 6.467074 & 2.918147 & 2.216158 & 0.0364 \\
\hline
\end{tabular}

\section{Conclusion}

Sector-based comparative advantage can be found by using several economic analysis models. In this analysis, Revealed Comparative Advantage (RCA) index is used to compare the competitiveness of olive oil industries of Spain, Italy, Turkey and Greece. In addition, a panel data regression is used to analyze the impact of several variables on RCA indexes of these countries. In final, it can be said that Turkey is the $3^{\text {rd }}$ country after Spain and Italy that has competitive advantage in olive oil industry. Turkey also has a potential to increase its current comparative advantage by making agricultural and trade policies that will increase the agricultural total factor productivity, financial development, research and development activities and market power. Turkey had imposed several policies in 2004 to be the $2^{\text {nd }}$ country in terms of producing olive oil in the world. It seems that Turkey is close to its target by being the $3^{\text {rd }}$ most competitive country in the olive oil industry. In addition to the impacts of variables which are analyzed in FMOLS regression, Turkey must motivate on policies that will well-manage the olive oil market structure in the country from the producers to the final consumer. As IOC, which is located in Spain, Turkey must instruct a research facility organization for olive oil industry researches and developments. Professional production models must be developed in order to increase the agricultural total factor productivity. Considering the 8 million of Turkish population who makes income from olive oil industry, these people must be educated and empowered to come together as cooperatives (Iliopoulos, 2012)

Turkish olive oil producers must be able to reach the government subventions efficiently and the funds must be controlled and monitored regularly. Cooperatives must exchange information with the farmers since the production begins from the farm first. Farmers must know the information first and fast on olive oil industry to improve the production.
Not only cooperatives need to be created and motivated on research and development, but also the olive farmers must be motivated on research and development. In this situation, the olive oil industry in Turkey as a whole will face the difficulties that may occur in the future, and as a whole will face the challenges to keep the current comparative advantage in the future. In addition to all of these factors that are explained so far, Turkey may think about the regulations about importation ban of olive oil from $3^{\text {rd }}$ countries. As Italy, Turkey must impose a regulation about zero tax reform on imported olive oil that is to be exported to $3^{\text {rd }}$ countries. This activity will also increase the knowing of Turkish olive oil brands and market power of Turkey in the global markets. In this research, mostly motivated on the production of olive oil and comparative advantage of mainly olive oil producers and exporters, which are Spain, Italy, Turkey and Greece. In future researches, olive oil consumption and mainly importers may be analysed to understand the olive oil industry widely.

\section{References}

Abay C, Türkekul B. 2006. Dünya zeytinyağı piyasasında rekabet analizi (pp. 1-7). Antalya: Türkiye Tarım Ekonomisi Kongresi Yayınları.

Anania G, Rosaira M. 2008. The global market for olive oil: Actors, trends, policies, prospects and research needs. Italy: University of Calabria.

Aydin K, Catuk C. 2018. The Effects of Inward Process Regime on the Vegetable Oil Sector's Foreign Trade in Turkey. Journal of Institute of Economic Development and Social Researches.

Bakırlığlu D. 2006. Avrupa Birliği'ndeki önemli zeytinyağ ihracatçıları ve Türkiye. İzmir: Dokuz Eylül Üniversitesi Yayınları.

Benedicts L. 2001. A note on the balassa index of revealed comparative advantage. Italy: Macerara University. 
Birișik N. 2016. Türkiye zeytincilik sektör raporu, (30): 1-25. İzmir: Zeytincilik Araştırma Enstitüsü Müdürlüğü Yayınları.

European Commission 2012. Economic analysis of olive oil sector. European Commission: Directorate General Agriculture and Rural Development.

Exports, Olive Oil 2019. Olive oil exports. Spain: International Olive Oil Council.

Seçer A, Emeksiz, F. 2018. Doğu akdeniz bölgesinde zeytin ve zeytinyağı pazarlama organizasyonu etkinliğinin değerlendirilmesi. Anadolu Tarım Bilimleri Dergisi, 34(1): 47-56.

Gürkan NP. 2015. Türk zeytin ve zeytinyağı sektörel yenilik sistemi: Fonksiyonel - yapısal bir analiz. Yayınlanmamış doktora tezi, Orta Doğu Teknik Üniversitesi, Ankara.

Iliopoulos C., Gerez S. 2012. Case study report: Structure and strategy of olive oil cooperatives: Comparing Crete, Greece to Andalusia, Spain. Spain: University of Almeria.
Lynch B, Rozema A. 2013. Olive oil: Conditions of competition between U.S. and major foreign supplier industries. United States of America: U.S. International Trade Commission.

Mylonas P. 2015. Olive oil: Establishing the Greek brand. Greece: National Bank of Greece Sectoral Report.

Serin V, Civan A. 2008. Revealed comparative advantage and competitivenes: a case study for Turkey towards the EU. Journal of Economics and Social Research, 10(2): 25-41.

Soyyiğit S, Yavuzaslan K. 2018. Complex network analysis of international olive oil market. Turkish Journal of Agricultural Economics, 24(2): 117-129.

Topçu BA, Sarıgül SS. 2015. Comparative advantage and the product mapping of exporting sectors in Turkey. The Journal of Academic Social Science, 3(14): 260-277.

Türkekul B, Günden C. 2010. Competitiveness of Mediterranean countries in the olive oil market. New Mediterranean, (9): 41-46.

Xiong B, Mathews W. 2014. New demand for old good: the U.S. demand for olive oil. United States of America: Agricultural Issues Center, University of California. 